\title{
Brand Management in US Business Schools: Can Yale Learn from Harvard?
}

Received (in revised form): April 8, 2004

\begin{abstract}
Anthony G. Heyes
Anthony G. Heyes is currently Professor of Economics at the University of London, and Head of the Economics Department at its Royal Holloway College. He has degrees from Cambridge and McGill Universities. His research interests are in regulation, environmental economics, and policy. He is a member of the editorial boards of the Journal of Environmental Economics and Management and the Journal of Regulatory Economics and has advised various European private and public bodies on regulatory matters.
\end{abstract}

\section{Catherine Liston-Heyes}

Dr. Catherine Liston-Heyes is a reader in business economics at the Royal Holloway School of Management at the University of London. Her research interests include consumer policy, corporate social responsibility, and environmental economics. She has published amongst other places in the Journal of Public Economics, the Journal of Environmental Economics and Management, and the Journal of Consumer Policy. She has degrees from the University of Ottawa and McGill University. She has worked at the University of London since 1993.

\begin{abstract}
Data Envelopment Analysis (DEA) is used to evaluate the performance of top US business school in maintaining reputation among members of the academic and business communities. The authors generate efficiency measures and identify peers against which underperforming schools should benchmark.
\end{abstract}

\section{Keyzords:}

business schools, reputation, marketing, Data Envelopment Analysis, best practice, benchmarking

\section{Author's Contact Address:}

Catherine Liston-Heyes

School of Management

Royal Holloway College

University of London

Egham, Surrey,

TW20 OEX, UK

Phone: + 44 (0)1784 443785

Fax: + 44 (0)1784 443785

Email: c.liston-heyes@rhul.ac.uk

\section{Introduction}

It is only shallow people who do not judge by appearances. (Oscar Wilde)

I wish I had a nickel for every student who's come up to me and asked where we rank in the US Neres. I could retire. (Dean Laurence M. Rose, University of Miami)

There are many elements to running a business school "well." While the CEO of a firm might be judged by simple summary measures such as financial profitability or share price (the latter capturing, as it does, the investors' evaluation of future profitability) the dean of a business school is expected to satisfy wider needs of constituents-intellectual as well as commercial.

We are interested here in the "brand management" aspect of running a school. In particular we ask the following 
question: which deans are successful in achieving a high reputation for their MBA programs, given underlying fundamentals? The qualification is important, here. It goes without saying that a dean would also take responsibility for enhancing those fundamentals-the research quality of faculty, level of available teaching resources and so forthbut here we focus exclusively on the reputation-building dimension. It should surprise no one that Harvard Business School commands a higher reputation among recruiters and academics than its counterpart at Vanderbilt-its measurable fundamentals are much stronger. But this doesn't necessarily mean that the Dean at Harvard should be commended on his reputation-building skills, any more than his counterpart at Vanderbilt should be rebuked. For that we would need to know whether the reputation commanded by one institution or the other was as great as it should be.

The outputs of educational institutions are notoriously difficult to quantify (embodied, as most of them are, in the human capital of graduates, or in scholarly pieces published in peer-reviewed journals). Our focus on brand reputation means that the current analysis-while more limited in scope-sidesteps many of these thorny problems. We use Data Envelopment Analysis (DEA) to analyze the relationship between a business school's reputation-its "output" in marketing terms-and a plausible set of fundamentals ("inputs"). The assumption is that reputation building is a productive activity that converts a number of inputs such as teaching and research resources into reputation. By characterizing the relationship between inputs and outputs it becomes possible to identify schools that are efficient in marketing terms-those maintaining a good reputation relative to their fundamentals-and those that are not. Best practice institutions can be identified. For schools not exhibiting best practice we can identify best practice "peers" against which the underperforming school can benchmark.

DEA is particularly applicable in setting where outputs and inputs are multidimensional, and where the appropriate weights to put on different outputs cannot be determined objectively. It is applicable in circumstances in which outputs are noncomparable (not measured on a common scale) and has been used for efficiency measurement, benchmarking, and the setting of performance targets in a variety of private and public sector applications. Trick notes that "DEA is an increasingly popular management tool." 1 Its use among management consultants has grown in recent years with the availability of easyto-use menu-driven software packages such as FrontierAnalyst.

We take as a starting point the assumption that business school managers are likely to be interested in maintaining a high reputation. "Reputation" in this context is an amorphous-and difficult to measure-concept. The difficulty in measurement has led to the controversy that surrounds the attempts by a number of organizations to construct league tables of business schools. We proceed on the basis that, other things equal, a dean would like to maintain a higher rather than lower reputation among several groups but, for current purposes, (1) prospective MBA employers (the business community) and (2) the academic community. Note that we do not need it to be the case that positions in league tables of this sort are the only or main things that motivate deans. We need simply accept that, other things equal, a business school will have a preference for 
a higher over a lower league position, and will seek to manage its "brand" accordingly.

The US Neres \& World Report (USNWR), which publishes the bestknown and much-cited annual ratings of US business school programs, publishes both reputation measures based on extensive surveys of opinion. We adopt these as the reputational outputs in our analysis. We do not need to accept the methodologies used, simply that these outputs are influential-something which is surely incontestable. How the two should be weighed-the respective weight that should be placed on impressing the two communities-is, however, a matter of opinion, and an opinion that might legitimately vary between institutions. DEA allows the evaluation of a best practice frontier without having to specify that weight. The analysis will, then, only allow us to make statements regarding the performance of a given unit relative to best practice exhibited by other units in the sector. Of course, if we were willing to impose a particular weighting scheme we might additionally be able to make comparisons between different units at different places on the frontier.

Rankings of business schools in general, and MBA programs in particular, have a controversial history both in the United States and internationally. The same applies to other professional disciplinesparticularly law. There is little doubt, though, that league positions matter. As one observer asserts:

Deans fear the rankings, and they hate them. At the same time they play to the rankings and use them to their advantage ... (while complaining about them) deans have never worked harder to land as high on the list as possible. Rankings bring pressure from chancellors, university presidents, and alumni to move their schools up, or at least recover from slides. For some the word has been "Get the numbers up, whatever it takes-or else."2

It is certainly the case that many schools make heavy use of high league position in promotional materials. Machung notes that: "Paradoxically, while higher education leaders are quick to criticize the annual rankings by the $U S N W R$, their institutions aggressively use the rankings to promote themselves in the race for visibility." ${ }^{3}$ The use of rankings in business school PR is explored by Staroba. ${ }^{4}$ Monks and Ehrenbergh show that league positions have a significant impact on admissions outcomes and program pricing decisions, at least among business schools located within private universities. $^{5}$

\section{Methodology}

DEA is a mathematical programming technique, increasingly popular as a management tool. Early uses of the nonparametric approach include Farrell and Charnes et al. ${ }^{6}$ Notable theoretical contributions include Seiford and Thrall, Andersen et al., and Banker. ${ }^{7}$ The technique identifies a best practice frontier which is made up of "decisionmaking units" (DMUs) that are nondominated with respect to their outputs and inputs, and convex combinations of observed nondominated units. Good overviews of the theory and practice of DEA are provided by Ganley and Cubbin, Charnes et al., and Cooper et al. ${ }^{8}$

In this study the DMUs are the individual business schools, and our interest is in their efficiency marketingbuilding reputation within the academic and employer communities. 


\section{Inputs and outputs}

We contend that the marketing output of a business school is reputation among two key audiences-the business community (and, specifically, MBA recruiters) and the academic community. We adopt as measures of these the "reputation surveys" contained in the 2000-1 rankings published by USNWR and restrict analysis to the top $50 \mathrm{MBA}$ providers. Though a variety of other publications (the Financial Times, Forbes, and others) provide alternative rankings, the USNWR is commonly regarded as the most influential.

USNWR takes the two reputational measures and six other indicators of academic quality and aggregates them to arrive at a single measure of quality from which they rank MBA programs. As with league tables in many other settings, aggregation is ad hoc and involves assigning subjective weights to the alternative indicators. The weightings used can impact rankings substantially and it is not surprising that they are surrounded by a lot of contention and cynicism. These weighting issues need not detain us here; DEA does not require that weights be specified.

Inputs to reputation are the fundamentals of the MBA program and the delivering institution. Theses are, in effect, what the dean of a business school has to "sell." Nine inputs have been incorporated into the model; each proxies one of the five recognized dimensions of business education quality. Student quality is proxied by the unweighted average of Graduate Management Admissions Test (GMAT) and grade point average (GPA) scores of incoming students. (The GMAT is assessed out of 800 while the maximum possible GPA is 4.) These were converted into percentages and the mean value assigned to each institution. Teaching resources is measured by admission fees and by staff-student ratios. Market value of the degree is proxied by the percentage of students finding jobs upon graduation as well as their starting salary. The USNWROnline attributes reputation scores to each university as a whole and these are used as our measure of institutional reputation. This variable was included on the assumption that the reputation of a particular MBA program is likely to be influenced not just by the quality of the business school, but also by the overall quality of the institution in which that school is embedded. Finally, research rating is measured in two ways-(1) the proportion of full-time staff with Ph.D.s and (2) the frequency with which faculty publish in a designated set of leading management journals. (Most of the research rating data was obtained from the Financial Times MBA 2000 survey. The business schools were asked to submit what they considered the three leading journal titles in 11 categories. The total number of publications for each school in the three most popular journals for each category were collected and adjusted for faculty size.) Table 1 provides summary statistics of the input variables.

The DEA produces efficiency measures which quantify, in one way or another, a "distance" to the efficient frontier of the (reputation) technology. The program employed here is the Efficiency Measurement System (EMS) Version 1.3-a software for Windows NT that computes DEA measures using the Linear Programming Solver DLL BPMPD 2.11. The technology chosen assumes a convex envelopment technology structure with constant returns to scale and radial distance measure. We also selected an output orientation in such a way that the efficiency scores quantify the output expansion needed to reach the best 
Table 1: Descriptive statistics of the quality inputs

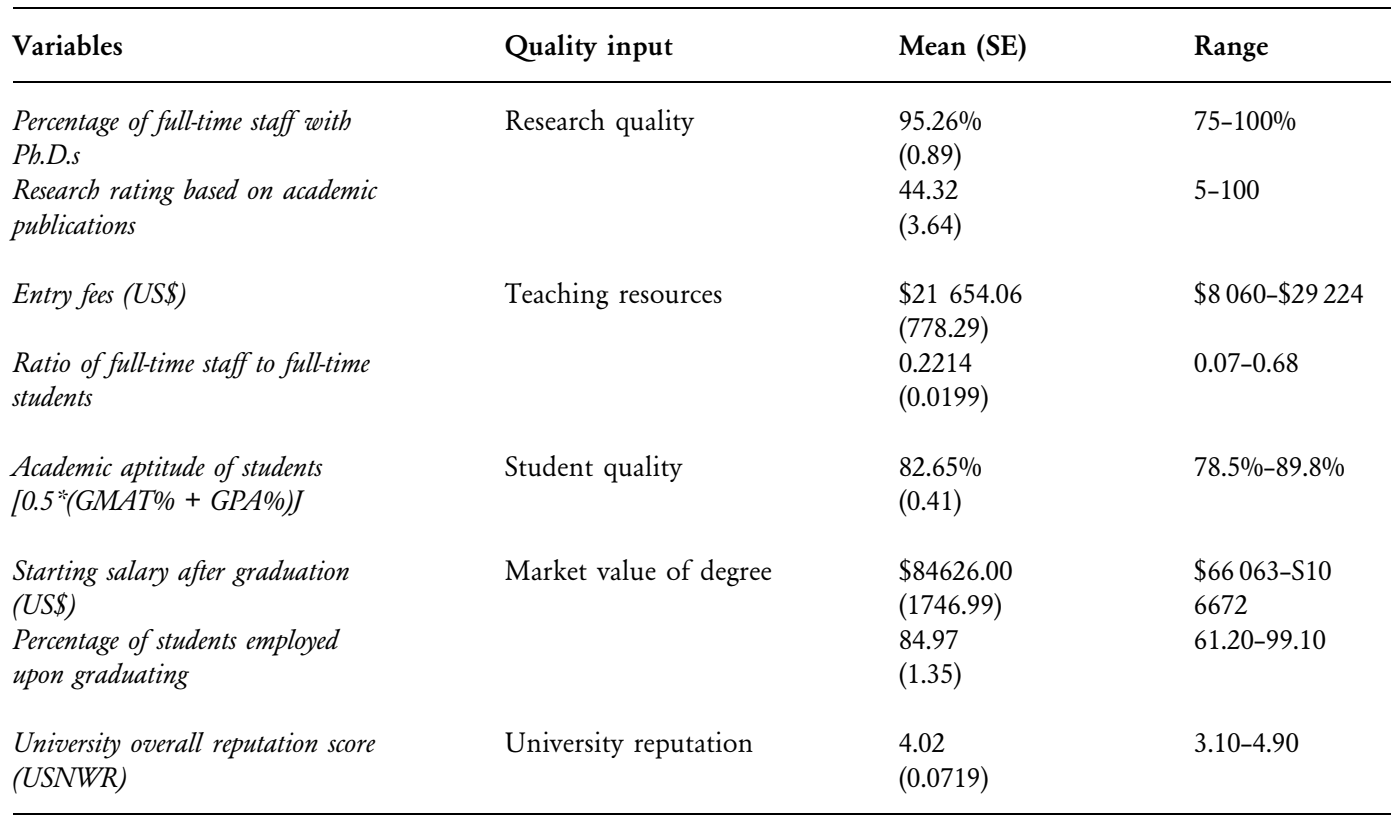

practice frontier holding the inputs constant. These are common assumptions in DEA programming. ${ }^{9}$

We used DEA and statistical analyses to do three things: (1) identify those schools that exhibit best practice in maintaining esteem in the business community, academic community and/or in the joint community; (2) for inefficient schools (those not on the best practice frontier) provide a measure of inefficiency, which could form the basis for a performanceimprovement target; (3) for inefficient schools identify best practice schools which could serve as appropriate benchmarks (i.e., those with similar input profiles).

\section{Results}

For completeness three separate DEAs were performed. Two rest on the assumption that the objective of schools is to maximize the reputation from either the academic or the recruiter community.
These are less interesting than the third which allows that reputations in both communities matter, though with respective weights that we are unable (and not required) to specify and which are likely, indeed, to vary among institutions. This is the "joint reputation" case.

Table 2 presents results from the three analyses. The institutions are ranked by their efficiency measure under "joint reputation" (alphabetically where efficiency measures equate). An efficiency measure equal to 100 percent means that the institution is on the best practice frontier. There are 23 schools on the best practice frontier in the joint case ("champions"). Since the DEA program is output oriented, scores above 100 percent suggests that there is scope for the DMU to improve its reputation given its level of inputs-the higher the score, the larger the potential improvement. For example, given the fundamental qualities of its school and program, the Smith School at 
Table 2: Efficiency scores, number of citations, and peer group composition per reputation category

\begin{tabular}{|c|c|c|c|c|c|c|c|}
\hline \multicolumn{2}{|c|}{ Institution } & \multicolumn{2}{|c|}{ Reputation with academics } & \multicolumn{2}{|c|}{ Reputation with recruiters } & \multicolumn{2}{|c|}{ Joint reputation } \\
\hline & & $\begin{array}{l}\text { Score } \\
\%\end{array}$ & $\begin{array}{l}\text { No. citations } \\
\text { or peer group }\end{array}$ & $\begin{array}{l}\text { Score } \\
\%\end{array}$ & $\begin{array}{l}\text { No. citations } \\
\text { or peer group }\end{array}$ & $\begin{array}{l}\text { Score } \\
\%\end{array}$ & $\begin{array}{l}\text { No. citations } \\
\text { or peer group }\end{array}$ \\
\hline 1 & $\begin{array}{l}\text { Carnegie Mellon } \\
\text { University }\end{array}$ & 100.00 & $\begin{array}{l}\text { Citations in peer } \\
\text { groups } 19\end{array}$ & 100.00 & $\begin{array}{l}\text { Citations in peer } \\
\text { groups } 1\end{array}$ & 100.00 & $\begin{array}{l}\text { Citations in peer } \\
\text { groups } 9\end{array}$ \\
\hline 2 & $\begin{array}{l}\text { Cornell University } \\
\text { (Johnson) }\end{array}$ & 100.00 & $\begin{array}{l}\text { Citations in peer } \\
\text { groups } 0\end{array}$ & 100.00 & $\begin{array}{l}\text { Citations in peer } \\
\text { groups } 2\end{array}$ & 100.00 & $\begin{array}{l}\text { Citations in peer } \\
\text { groups } 0\end{array}$ \\
\hline 3 & Harvard University & 100.00 & $\begin{array}{l}\text { Citations in peer } \\
\text { groups } 5\end{array}$ & 100.00 & $\begin{array}{l}\text { Citations in peer } \\
\text { groups } 11\end{array}$ & 100.00 & $\begin{array}{l}\text { Citations in peer } \\
\text { groups } 4\end{array}$ \\
\hline 4 & $\begin{array}{l}\text { Thunderbird } \\
\text { Graduate School }\end{array}$ & 100.00 & $\begin{array}{l}\text { Citations in peer } \\
\text { groups } 0\end{array}$ & 100.00 & $\begin{array}{l}\text { Citations in peer } \\
\text { groups } 26\end{array}$ & 100.00 & $\begin{array}{l}\text { Citations in peer } \\
\text { groups } 9\end{array}$ \\
\hline 5 & $\begin{array}{l}\text { Uni. of California } \\
\text { Los Angeles }\end{array}$ & 100.00 & $\begin{array}{l}\text { Citations in peer } \\
\text { groups } 9\end{array}$ & 100.00 & $\begin{array}{l}\text { Citations in peer } \\
\text { groups } 0\end{array}$ & 100.00 & $\begin{array}{l}\text { Citations in peer } \\
\text { groups } 3\end{array}$ \\
\hline 6 & $\begin{array}{l}\text { University of } \\
\text { Pennsylvania }\end{array}$ & 100.00 & $\begin{array}{l}\text { Citations in peer } \\
\text { groups } 5\end{array}$ & 100.00 & $\begin{array}{l}\text { Citations in peer } \\
\text { groups } 3\end{array}$ & 100.00 & $\begin{array}{l}\text { Citations in peer } \\
\text { groups } 3\end{array}$ \\
\hline 7 & $\begin{array}{l}\text { University of Virginia } \\
\text { (Darden) }\end{array}$ & 100.00 & $\begin{array}{l}\text { Citations in peer } \\
\text { groups } 10\end{array}$ & 100.00 & $\begin{array}{l}\text { Citations in peer } \\
\text { groups } 10\end{array}$ & 100.00 & $\begin{array}{l}\text { Citations in peer } \\
\text { groups } 8\end{array}$ \\
\hline 8 & NorthWestern University & 100.22 & Peer group $\{6,3,7\}$ & 100.00 & $\begin{array}{l}\text { Citations in peer } \\
\text { groups } 4\end{array}$ & 100.00 & $\begin{array}{l}\text { Citations in peer } \\
\text { groups } 0\end{array}$ \\
\hline 9 & $\begin{array}{l}\text { University of Texas } \\
\text { (Austin) }\end{array}$ & 101.68 & Peer group $\{5,7,3\}$ & 100.00 & $\begin{array}{l}\text { Citations in peer } \\
\text { groups } 18\end{array}$ & 100.00 & $\begin{array}{l}\text { Citations in peer } \\
\text { groups } 7\end{array}$ \\
\hline 10 & Duke University (Fuqua) & 102.99 & Peer group $\{3,7,21\}$ & 100.00 & $\begin{array}{l}\text { Citations in peer } \\
\text { groups } 1\end{array}$ & 100.00 & $\begin{array}{l}\text { Citations in peer } \\
\text { groups } 1\end{array}$ \\
\hline 11 & $\begin{array}{l}\text { University of North } \\
\text { Carolina }\end{array}$ & 103.57 & Peer group $\{5,22,23\}$ & 100.00 & $\begin{array}{l}\text { Citations in peer } \\
\text { groups } 3\end{array}$ & 100.00 & $\begin{array}{l}\text { Citations in peer } \\
\text { groups } 4\end{array}$ \\
\hline 12 & $\begin{array}{l}\text { University of } \\
\text { Michigan }\end{array}$ & 107.52 & Peer group $\{16,6\}$ & 100.00 & $\begin{array}{l}\text { Citations in peer } \\
\text { groups } 10\end{array}$ & 100.00 & $\begin{array}{l}\text { Citations in peer } \\
\text { groups } 4\end{array}$ \\
\hline 13 & $\begin{array}{l}\text { Rice University } \\
\text { (Jones) }\end{array}$ & 150.00 & Peer group $\{1\}$ & 100.00 & $\begin{array}{l}\text { Citations in peer } \\
\text { groups } 0\end{array}$ & 100.00 & $\begin{array}{l}\text { Citations in peer } \\
\text { groups } 0\end{array}$ \\
\hline 14 & $\begin{array}{l}\text { Georgia Institute of } \\
\text { Technology }\end{array}$ & 210.00 & Peer group $\{1\}$ & 100.00 & $\begin{array}{l}\text { Citations in peer } \\
\text { groups } 2\end{array}$ & 100.00 & $\begin{array}{l}\text { Citations in peer } \\
\text { groups } 2\end{array}$ \\
\hline 15 & $\begin{array}{l}\text { Brigham Young } \\
\text { University }\end{array}$ & 141.25 & Peer group $\{1,23\}$ & 100.00 & $\begin{array}{l}\text { Citations in peer } \\
\text { groups } 11\end{array}$ & 100.00 & $\begin{array}{l}\text { Citations in peer } \\
\text { groups } 5\end{array}$ \\
\hline 16 & Stanford University & 100.00 & $\begin{array}{l}\text { Citations in peer } \\
\text { groups } 16\end{array}$ & 100.72 & Peer group $\{6,4\}$ & 100.00 & $\begin{array}{l}\text { Citations in peer } \\
\text { groups } 8\end{array}$ \\
\hline 17 & $\begin{array}{l}\text { Columbia } \\
\text { University }\end{array}$ & 100.00 & $\begin{array}{l}\text { Citations in peer } \\
\text { groups } 0\end{array}$ & 100.93 & Peer group $\{2,3\}$ & 100.00 & $\begin{array}{l}\text { Citations in peer } \\
\text { groups } 0\end{array}$ \\
\hline 18 & $\begin{array}{l}\text { Indiana } \\
\text { University }\end{array}$ & 100.10 & Peer group $\{7,23\}$ & 103.74 & Peer group $\{9,7\}$ & 100.00 & $\begin{array}{l}\text { Citations in peer } \\
\text { groups } 1\end{array}$ \\
\hline 19 & $\begin{array}{l}\text { University of } \\
\text { Chicago }\end{array}$ & 100.00 & $\begin{array}{l}\text { Citations in peer } \\
\text { groups } 0\end{array}$ & 104.09 & Peer group $\{3,2\}$ & 100.00 & $\begin{array}{l}\text { Citations in peer } \\
\text { groups } 0\end{array}$ \\
\hline 20 & $\begin{array}{l}\text { New York University } \\
\text { (Stern) }\end{array}$ & 100.00 & $\begin{array}{l}\text { Citations in peer } \\
\text { groups } 1\end{array}$ & 105.00 & Peer group $\{4,8\}$ & 100.00 & $\begin{array}{l}\text { Citations in peer } \\
\text { groups } 1\end{array}$ \\
\hline 21 & $\begin{array}{l}\text { Dartmouth } \\
\text { University (Tuck) }\end{array}$ & 100.00 & $\begin{array}{l}\text { Citations in peer } \\
\text { groups } 2\end{array}$ & 108.77 & Peer group $\{3,4\}$ & 100.00 & $\begin{array}{l}\text { Citations in peer } \\
\text { groups } 1\end{array}$ \\
\hline 22 & $\begin{array}{l}\text { Uni. of California } \\
\text { Berkeley }\end{array}$ & 100.00 & $\begin{array}{l}\text { Citations in peer } \\
\text { groups } 8\end{array}$ & 110.33 & Peer group $\{11,3\}$ & 100.00 & $\begin{array}{l}\text { Citations in peer } \\
\text { groups } 3\end{array}$ \\
\hline 23 & $\begin{array}{l}\text { University of } \\
\text { Arizona }\end{array}$ & 100.00 & $\begin{array}{l}\text { Citations in peer } \\
\text { groups } 12\end{array}$ & 251.08 & Peer group $\{9\}$ & 100.00 & $\begin{array}{l}\text { Citations in peer } \\
\text { groups } 4\end{array}$ \\
\hline 24 & $\begin{array}{l}\text { University of } \\
\text { Rochester }\end{array}$ & 100.37 & Peer group $\{7,1\}$ & 126.60 & Peer group $\{4,9\}$ & 100.37 & Peer group $\{7,1\}$ \\
\hline 25 & $\begin{array}{l}\text { Uni. of Minnesota- } \\
\text { Twin Cities }\end{array}$ & 101.47 & Peer group $\{7,5\}$ & 182.79 & Peer group $\{9\}$ & 101.47 & Peer group $\{7,5\}$ \\
\hline
\end{tabular}


Table 2: Continued

\begin{tabular}{|c|c|c|c|c|c|c|c|}
\hline \multicolumn{2}{|c|}{ Institution } & \multicolumn{2}{|c|}{ Reputation with academics } & \multicolumn{2}{|c|}{ Reputation with recruiters } & \multicolumn{2}{|c|}{ Joint reputation } \\
\hline & & $\begin{array}{l}\text { Score } \\
\%\end{array}$ & $\begin{array}{l}\text { No. citations } \\
\text { or peer group }\end{array}$ & $\begin{array}{l}\text { Score } \\
\%\end{array}$ & $\begin{array}{l}\text { No. citations } \\
\text { or peer group }\end{array}$ & $\begin{array}{l}\text { Score } \\
\%\end{array}$ & $\begin{array}{l}\text { No. citations } \\
\text { or peer group }\end{array}$ \\
\hline 26 & MIT Sloan & 104.54 & Peer group $\{16,6\}$ & 107.09 & Peer group $\{12,3\}$ & 103.61 & Peer group $\{6\}$ \\
\hline 27 & Uni. of Illi.-Urb.-Champ. & 105.38 & Peer group $\{1,16\}$ & 141.18 & Peer group $\{4\}$ & 105.38 & Peer group $\{1,16\}$ \\
\hline 28 & Purdue University & 111.43 & Peer group $\{5,22\}$ & 110.10 & Peer group $\{9\}$ & 106.32 & Peer group $\{9\}$ \\
\hline 29 & Michigan State University & 127.94 & Peer group $\{23,5\}$ & 107.26 & Peer group $\{9\}$ & 107.17 & Peer group $\{9,11\}$ \\
\hline 30 & $\begin{array}{l}\text { Uni. of Wisconsin- } \\
\text { Madison }\end{array}$ & 110.81 & Peer group $\{16,1\}$ & 123.37 & Peer group $\{12,9,4\}$ & 110.10 & Peer group $\{16,7\}$ \\
\hline 31 & Uni. of Notre Dame & 202.14 & Peer group $\{1\}$ & 110.19 & Peer group $\{4,14\}$ & 110.19 & Peer group $\{4,14\}$ \\
\hline 32 & Yale University & 113.46 & Peer group $\{21,7,3\}$ & 120.90 & Peer group $\{3,4\}$ & 113.18 & Peer group $\{21,3\}$ \\
\hline 33 & $\begin{array}{l}\text { Washington Uni. } \\
\text { in St-Louis }\end{array}$ & 113.59 & Peer group $\{16,1\}$ & 140.90 & Peer group $\{12,4\}$ & 113.59 & Peer group $\{16,1\}$ \\
\hline 34 & $\begin{array}{l}\text { Ohio State } \\
\text { University }\end{array}$ & 120.18 & Peer group $\{23,5\}$ & 121.33 & Peer group $\{9\}$ & 114.02 & Peer group $\{9\}$ \\
\hline 35 & $\begin{array}{l}\text { Uni. of Southern } \\
\text { California }\end{array}$ & 114.37 & Peer group $\{1,6\}$ & 129.83 & Peer group $\{4,7,8\}$ & 114.37 & Peer group $\{1\}$ \\
\hline 36 & $\begin{array}{l}\text { Georgetown } \\
\text { University }\end{array}$ & 183.82 & Peer group $\{7,1\}$ & 121.35 & Peer group $\{7,4\}$ & 121.35 & Peer group $\{7,4\}$ \\
\hline 37 & Emory University & 134.99 & Peer group $\{16,1,7\}$ & 126.32 & Peer group $\{7,4,12\}$ & 125.44 & Peer group $\{7,4\}$ \\
\hline 38 & $\begin{array}{l}\text { Vanderbilt } \\
\text { University }\end{array}$ & 144.15 & Peer group $\{3,7\}$ & 126.23 & Peer group $\{10\}$ & 126.23 & Peer group $\{10\}$ \\
\hline 39 & $\begin{array}{l}\text { Texas A\&M } \\
\text { University }\end{array}$ & 141.30 & Peer group $\{22,23\}$ & 155.26 & Peer group $\{15,9\}$ & 131.78 & Peer group $\{11\}$ \\
\hline 40 & $\begin{array}{l}\text { University of } \\
\text { Maryland (Smith) }\end{array}$ & 138.75 & Peer group $\{5,23\}$ & 134.56 & Peer group $\{9\}$ & 132.43 & Peer group $\{9,5\}$ \\
\hline 41 & Penn State Uni.-Uni. Park & 181.90 & Peer group $\{22,23\}$ & 139.57 & Peer group $\{9\}$ & 139.57 & Peer group $\{9\}$ \\
\hline 42 & $\begin{array}{l}\text { Case Western } \\
\text { Reserve Uni. }\end{array}$ & 172.40 & Peer group $\{1\}$ & 151.20 & Peer group $\{4,7\}$ & 151.20 & Peer group $\{4,7\}$ \\
\hline 43 & Arizona State University & 154.38 & Peer group $\{22,23\}$ & 220.11 & Peer group $\{11,15\}$ & 154.20 & Peer group $\{22,23\}$ \\
\hline 44 & $\begin{array}{l}\text { University of } \\
\text { Georgia }\end{array}$ & 172.02 & Peer group $\{23\}$ & 248.66 & Peer group $\{9,15\}$ & 170.43 & Peer group $\{18,23\}$ \\
\hline 45 & Boston College & 311.76 & Peer group $\{1\}$ & 182.70 & Peer group $\{4,14\}$ & 182.70 & Peer group $\{4,14\}$ \\
\hline 46 & $\begin{array}{l}\text { Wake Forest } \\
\text { University }\end{array}$ & 339.46 & Peer group $\{1\}$ & 186.16 & Peer group $\{4,9\}$ & 186.16 & Peer group $\{4,9\}$ \\
\hline 47 & Tulane University & 352.30 & Peer group $\{1,16\}$ & 189.11 & Peer group $\{4\}$ & 189.11 & Peer group $\{4\}$ \\
\hline 48 & $\begin{array}{l}\text { Southern Methodist } \\
\text { University }\end{array}$ & 209.16 & Peer group $\{20,1\}$ & 242.08 & Peer group $\{4\}$ & 209.15 & Peer group $\{20,1\}$ \\
\hline 49 & $\begin{array}{l}\text { University of California- } \\
\text { Davis }\end{array}$ & 358.94 & Peer group $\{16,1\}$ & 4732.20 & Peer group $\{4,9,12\}$ & 358.94 & Peer group $\{16,1\}$ \\
\hline 50 & $\begin{array}{l}\text { University of California- } \\
\text { Irvine }\end{array}$ & 401.71 & Peer group $\{1\}$ & 4851.58 & Peer group $\{4,9\}$ & 401.71 & Peer group $\{16\}$ \\
\hline & Mean efficiency score & 172.22 & & 316.27 & & 127.60 & \\
\hline & Mean inefficiency score & 200.31 & & 408.95 & & 151.11 & \\
\hline
\end{tabular}

the University of Maryland should be able to raise its reputational performance by 32 percent. Some notable departures are apparent-particularly the striking underperformance of the two lesser-known
University of California programs at Davis and Irvine. What these numbers tell us is not that these are weak schools. Quite the contrary in fact-the reputations of these schools are very substantially 
lower than they should be given

fundamental strengths.

In the DEA literature it is conventional to calculate the mean efficiency score as a representative level of performance, although some authors suggest that the inclusion of best practice tends to overstate levels of performance. ${ }^{10}$ The mean efficiency scores (incorporating all schools) and the mean inefficiency scores (excluding best practice ones) are also listed and can be used to gauge representative levels of performance in each of the categories. From these we learn that the representative institution performs at its best within the joint community, with mean efficiency score of 127.6 percent and a mean inefficiency score of 151.1 percent.

The Venn diagram in Figure 1 summarizes graphically the sets of schools that exhibit best practice in terms of reputation in the academic community
(Set A-14 institutions); among recruiters (Set B-15 institutions); and in the joint community (Set $\mathrm{C}-23$ institutions).

Set $C$ is different than the intersection of Set A and Set B in that it is possible for an institution to "produce" efficiently across several product lines-here academic and recruiter reputation-without necessarily excelling in either. In our analysis, one school falls into this category (the Kelley School at Indiana University).

DEA is useful both in setting performance targets and in benchmarking. The efficiency scores provide a measure of the improvement that a school would be able to generate in its reputation by implementing best practice. It offers more constructive guidance, however, by identifying best practice "peers." For each nonchampion institution it identifies best practice firms with similar configurations of inputs. Those firms lie closest to the point on the best practice frontier to that

All others (27)

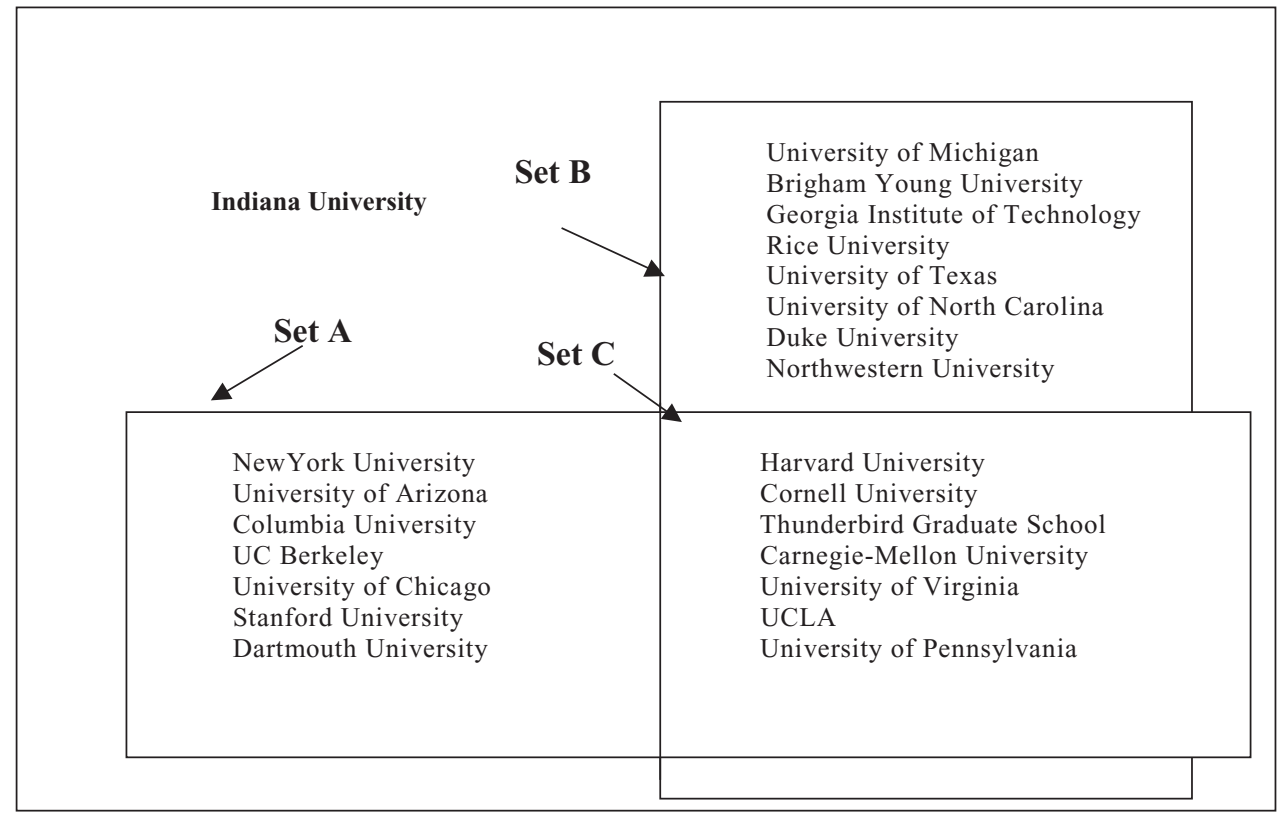

Figure 1: Venn diagram of "best-practice" business schools 
point at which the underperforming institution should be able to relocate itself.

One of the major attractions of DEA is that once a DMU has been classified as best practice-that is, on the efficiency frontier of reputation building-it allows inefficient organizations (or its auditors) to make comparisons with best practice ones in order to extract and transfer relatively better managerial procedures. Table 2 also lists the peer group upon which the inefficient institution should model itself. The DMU units in the peer group appear in decreasing order of importance (that is, the first institution provides a "closer" target than the subsequent ones). Peer group members with less than 0.20 intensities are excluded. Comparing peer groups in the first two categories (columns 4 and 6) reveals little overlap, highlighting the fact that efficient reputation management is contingent on whether the target audience is academic peers or employers.

The frequency with which an efficient institution is cited indicates where the most useful examples of best practice are likely to be found in heavily cited instances of best practice. These citation frequencies can also be extracted from Table 2. The champions of efficiency in reputation building (more than five citations) among academics are CarnegieMellon (19), Stanford University (16), University of Arizona (12), University of Virginia (Darden) (10), University of California at Los Angeles (9), and University of California at Berkeley (8). Among recruiters, though, these are outperformed by Thunderbird Graduate School (26), University of Texas (Austin) (18), Harvard University (11) Brigham Young University (11), University of Virginia (Darden) (10) (appearing again) and University of Michigan (10). The top models in the joint community category are Carnegie-Mellon (9) at par with Thunderbird Graduate School (9), University of Virginia (Darden) (8) at par with Stanford University (8), and University of Texas (Austin) (7).

To pick out a couple of examples-and to justify the subtitle of the paper-we note that MIT Sloan, with an efficiency score 103.6 percent in the most important joint case, has University of Pennsylvania (Wharton) as its closest benchmark. Yale (113.2\%) should benchmark against Harvard Business School and the Tuck School at Dartmouth.

Many DEA programs will include, for each inefficient DMU, the recommended savings (or "slacks") in each of the input categories-That is, it calculates equiproportionate contractions in each input based on the unit's efficiency scores and its peer group. It is neither practical nor interesting to examine these individually, but insights can be gained by determining whether the sources of inefficiencies differ in general and between the reputation categories.

With this in mind we conducted further statistical analyses on the data produced by the DEAs. Table 3 presents the results of independent samples t-test on the input "slacks"-the overspending on resources by nonbest practice units. When comparing the performance of inputs between reputation categories, we find that there exist statistically significant differences in the effectiveness of research ratings, tuition fees, student selection, starting salaries, and employment at graduation. More concretely, the DEA shows that research ratings are important in terms of reputation in the academic community but less so among employers (i.e., the slack in the later category is substantially higher). On the other hand, student selection (GMAT and GPA) and 
Table 3: Independent samples t-test : input slacks

\begin{tabular}{|c|c|c|c|c|}
\hline \multirow{2}{*}{$\begin{array}{l}\text { Quality dimensions } \\
\text { Research quality }\end{array}$} & \multirow{3}{*}{$\begin{array}{l}\text { Input variables } \\
\text { Number of full-time staff } \\
\text { with Ph.D. } \\
\text { Research rating }\end{array}$} & \multicolumn{2}{|c|}{$\begin{array}{l}\text { Mean slack: reputation with academics } \\
\text { Mean slack: reputation with recruiters }\end{array}$} & \multirow{2}{*}{$\begin{array}{c}\begin{array}{c}\text { Equal variances } \\
\text { (Levene's Test) }\end{array} \\
\text { Yes }\end{array}$} \\
\hline & & $\begin{array}{l}17.97 \% \\
14.67 \%\end{array}$ & Mean difference $3.35 \%$ & \\
\hline & & $\begin{array}{l}1.20 \\
7.10\end{array}$ & Mean difference $5.90 \%$ & No \\
\hline \multirow[t]{2}{*}{ Teaching resources } & Tuition fees & $\begin{array}{l}\text { US\$ } 1875.66 \\
\text { US\$ } 827.73\end{array}$ & $\begin{array}{l}\text { Mean difference } \\
\text { US\$ } 1047.94^{* * *}\end{array}$ & No \\
\hline & FT staff:FT student ratio & $\begin{array}{l}0.12 \\
0.12\end{array}$ & Mean difference 0 & Yes \\
\hline Student quality & $\begin{array}{l}\text { Student selection } \\
\text { (CPA, GMAT) }\end{array}$ & $\begin{array}{l}14.05 \% \\
4.16 \%\end{array}$ & Mean difference $9.88 \% 0^{* * *}$ & No \\
\hline \multirow[t]{2}{*}{$\begin{array}{l}\text { Market value of } \\
\text { degree }\end{array}$} & Starting salary & $\begin{array}{l}\text { US\$ } 6684.91 \\
\text { US\$ } 2888.13\end{array}$ & $\begin{array}{l}\text { Mean difference } \\
\text { US\$ } 3796.77^{* * *}\end{array}$ & No \\
\hline & Employment at graduation & $\begin{array}{l}15.42 \% \\
7.83 \%\end{array}$ & Mean difference $7.59 \%$ & No \\
\hline $\begin{array}{l}\text { University } \\
\text { reputation }\end{array}$ & University reputation score & $\begin{array}{l}1.07 \\
1.08\end{array}$ & Mean difference 0.013 & No \\
\hline
\end{tabular}

*** significant at the 0.05 level

market value of degree (starting salary and percentage employed at graduation) are assets that impress the business community more than the academic one. There are no statistically significant differences in the slacks associated with the number of full-time staff to student ratio, the number of full-time staff with Ph.D.s, or university reputation, suggesting that none of these inputs are comparatively more important with one audience than any other.

\section{Conclusions}

Whatever we may think about league tables it is undeniable that business school managers care about the reputation of their programs. DEA provides us with a tool to investigate-and quantify-the efficiency with which "inputs" (the fundamental characteristics of the school, its staff, students and programs) are converted into the output of "reputation."
The results of the DEA presented here tell us (1) which schools exhibit best practice in their marketing, and which don't, (2) for each one that doesn't, the extent to which it underperforms, and (3) against which other school it should benchmark. Thus, the reputation of the Yale Graduate School of Business-though high-is 13 percent below what it should be given its fundamental strengths. If it wants someone to copy, it should look to Harvard.

\section{References}

1. M. Trick (2001), Data Envelopment Analysis for Consultants, available at <http://mat.gsia.cmu.edu/ $\mathrm{mstc} / \mathrm{dea} / \mathrm{dea} \cdot \mathrm{html}$.

2. T. Carter (1998), "Rankled by rankings," $A B A$ Journal 84 (March), pp. 46-53, quotation at pp.46-7.

3. A. Machung (1998), "Playing the rankings game," Change 30, 4, pp.12-16, quotation at p.12.

4. K. Staroba (1997), "The rankings ruckus: PR pros talk about how-and how not-to publicise college rankings,"Currents, 23, 6, pp. 30-5.

5. J. Monks and R. G. Ehrenbergh (1999), "The impact of US Neres and World Report college rankings on 
admissions outcomes and pricing decisions at selective private institutions," NBER Working Paper No. 7727, National Bureau of Economic Research, Cambridge MA.

6. M. Farrell (1957), "The measurement of productive efficiency," Journal of the Royal Statistical Society (Series A), 120, pp. 253-81; A. Charnes, W. W. Cooper and E. Rhodes (1978), "Measuring the efficiency of decision-making units," European Journal of Operational Research, 2, pp. 429-44; A. Charnes, W. W. Cooper and E. Rhodes (1981), "Evaluating program and managerial efficiency: An application of data envelopment analysis," Management Science, 27, pp. 668-97.

7. L. M. Seiford and R. M. Thrall (1990), "Recent developments in DEA: the mathematical programming appoach to frontier analysis," Journal of Econometrics, 46, pp. 7-38; P. Andersen and N. C. Petersen (1993), "A procedure for ranking efficient units in data envelopment analysis," Management Science 39, 10, pp. 1261-4; R. D. Banker (1993), "Maximum likelihood, consistency and data envelopment analysis: a statistical foundation," Management Science 39, 10, pp. 1265-73.

8. J. A. Ganley and J. S. Cubbin (1992), Public Sector Efficiency Measurement. North Holland, Amsterdam; A. Charnes, W. W. Cooper, A. Y. Lewin, and L. M. Seiford (1993), Data Envelopment Analysis: Theory, Methodology, and Applications, Oxford University Press, New York; W. W. Cooper, L. M. Seiford, and K. Tone (2000), Data Envelopment Analysis: A Comprehensive Text with Models, Applications, References and DEA-Solver Software, Kluwer Academic Publishers, Norwell, MA.

9. See, e.g., H. O. Fried, C. A. K. Lovell, and S. Schmidt (1993), The Measurement of Productive Efficiency: Techniques and Applications, Oxford University Press, New York; Charnes et al. (1993), Data Envelopment Analysis: Theory, Methodology, and Applications, op. cit.; Cooper at al. (2000), Data Envelopment Analysis: A Comprehensive Text, op. cit.

10. See Ganley and Cubbin (1992), Public Sector Efficiency Measurement, op. cit. 